\title{
KoREAN AND JAPANESE AS CHINESE-ChARACTERS CULTURAL SPHERES
}

\author{
Takuya OKIMORI \\ Rikkyo University \\ okimori@rikkyo.ac.jp
}

\begin{abstract}
Korea and Japan belong to Chinese-characters cultural spheres. In the time of Han Dynasty and thereafter, tributary states connected with the monarchy of Chinese Kingdom and its surrounding countries. They imported Chinese state regulations, accepted and developed many thoughts and cultures by bringing in Chinese characters of Chinese classics. However, there have been some different points in the treatment of Chinese characters in each nation. The Korean modern writing system does not use Chinese characters in general, while on the contrary in Japanese, there is a tendency to increase the number of regularly-used Chinese characters, for example in the official list of joȳo kanji 常用漢字 announced by the Ministry of Education, with the latest increase in 2010. Therefore, it is necessary to observe more about some aspects of the languages to know why this different treatment occurred. The oldest Korean document is the History of the Three Kingdoms, Samguk Sagi 『三国史記』 that contains geographical proper names. The Buyeo-Kingdom languages were recorded there, including place names. It is no doubt that the use of Chinese characters of Silla have significantly affected Goguryeo and Paekche. The Silla and Buyeo-Kingdom languages have closed syllables with a consonant at the end of each syllable, while in Japanese, the syllables end with vowels as open syllables. There are further phonological characteristics as well. This article discusses how each language encountered Chinese characters, and how they related to their specific languages, and also how Chinese characters particularly reflected syllable structures of different languages. It can be said that the use of Chinese characters in proper names estranged the futures of Korean and Japanese in history. Focus is laid on the history of Korean and Japanese through Chinese characters, with their falsely similar language dispositions.
\end{abstract}

Keywords: Korean; Japanese; kun (semantic) reading; geographical notation; writing system

\section{Povzetek}

Koreja in Japonska sta obe v kulturnem področju kitajskih pismenk. V času Han dinastije in kasneje so se tributarne države povezale z monarhijo Kitajsko in drugimi dražavami ogrog nje. Uvažali so kitajska klasična dela in z njimi kitajske pismenke, sprejeli in razvili so državni

Acta Linguistica Asiatica, 4(3), 2014.

ISSN: 2232-3317, http://revije.ff.uni-lj.si/ala/

DOI: 10.4312/ala.4.3.43-70 
pravilnik, mnoge misli in druge kulturne prvine. Med nacijami so obstajali tudi razlike v načinu sprejemanja in rabe kitajskih pismenk. Med tem ko današnji korejski sistem pisave nasplošno ne uporablja kitajskih pismenk, na Japonskem se število uporabljenih pismenk, t.i.joyo kanji 常用 漢字 celo veča, zadnji odlok Ministrstva za šolstvo iz leta 2010. Da bi ugotovili točno, zakaj so takšne razlike, moramo opazovati nekaj jezikovnih pogojev. Najstarejši korejski zgodovinski zapis je Zgodovina treh kraljevin Samguk Sagi『三国史記』, ki vsebuje krajevna lastna imena. Zapisani so v jezikih tedanje kraljevine Buyeo. Nedvomno je, da je raba kitajskih pismenk v naciji Silla znatno vplivala na rabo v Goguryeu in Paekcheju. Jezik v Silli in jeziki v kraljevini Buyeo so imeli zaprte zlogove s soglasnikom na koncu vsake zloge, medtem ko je japonščina imela odprte zlogove s samoglasnikom na koncu. Obstajajo še druge fonološke značilnosti. Članek obravnava srečanje in sprejemanje kitajskih pismenk v vsakem jeziku glede na lastnosti le-tega, zlasti glede na strukturo zloga. Lahko trdimo, da je raba kitajskih pismenk za zapisovanje lastnih imen bil razlog za odtujevanje korejskega in japonskega jezika v kasnejšem času. V zgodovini korejskega in japonskega jezika razkrivamo navidezno podobne lastnosti obeh jezikov.

Ključne besede: korejščina; japonščina; kun (razlagalno) branje; zemljepisni zapis; sistem pisave

\section{The ancient use of Chinese characters in the Korean Peninsula}

It is said that Goguryeo ${ }^{1}$ was founded in $37 \mathrm{BC}$ by the people of $\mathrm{Buyeo}^{2}$, a Tungus nation. Some descendant people of Goguryeo then ruled Paekche ${ }^{3}$. It was probably some Tungus language which was spoken in Paekche. On the other hand, it is believed that the language of Silla ${ }^{4}$ is the father of present Korean language, and was different from the language of its rulers, Goguryeo and Paekche (Lee Gi-Mun 1975). (See Fig. 1)

1 高句麗. Goguryeo or Koguryo (Hangul: 고구려; hanja: 高句麗, Korean pronunciation: [kogurj $\Lambda$ ]) (37 BC - $668 \mathrm{AD})$ was one of the ancient Three Kingdoms of Korea. It located in the northern and central parts of the Korean Peninsula and the southern and central parts of inner and outer Manchuria. http://en.wikipedia.org/wiki/Goguryeo (accessed January 5th, 2015).

2 扶 余 Buyeo or Puyŏ (Korean pronunciation: [puj $\Lambda$ ]), Fuyu in Chinese, was an ancient kingdom. It located from today's Manchuria to northern North Korea, from around the 2nd century BC to 494. Its remnants were absorbed by the neighboring and brotherhood kingdom of Goguryeo.`http://en.wikipedia.org/wiki/Buyeo_kingdom (accessed January 5th, 2015).

3 百済 Baekje or Paekche (Hangul: 백제; hanja: 百濟, Korean pronunciation: [pektcee]) (18 BC - 660 AD) was a kingdom located in southwest Korea. It was one of the Three Kingdoms of Korea, together with Goguryeo and Silla. http://en.wikipedia.org/wiki/Baekje (accessed January 5th, 2015).

4 新羅 Silla (Korean pronunciation: [6hil:a]) (57 BC - 935 AD) was one of the Three Kingdoms of Korea, and one of the world's longest sustained dynasties. Silla eventually conquered the other two kingdoms, Baekje in 660 and Goguryeo in 668. http://en.wikipedia.org/wiki/Silla (accessed January 5th, 2015). 


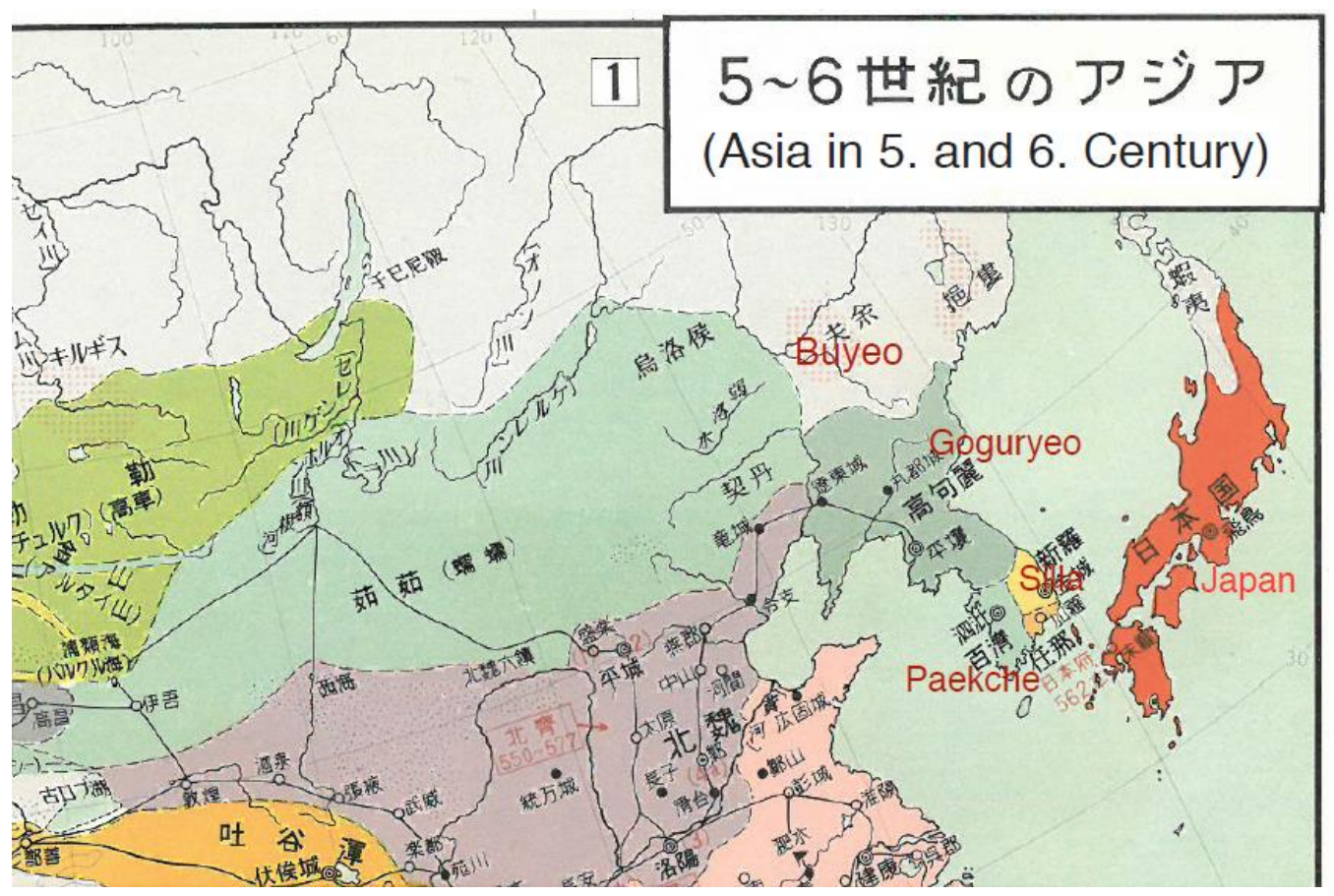

Figure 1: The language of Silla on the map, $5^{\text {th }}-6^{\text {th }}$ century.

In the corpus of written records of these three countries, aside from epigraphs (=inscriptions on stone and/or metal), there are Chinese historical documents and Nihon shoki 『日本書紀』, the oldest chronicles of Japan, but the greatest written record about Goguryeo and Paekche is the Korean chronicle called Samguk Sagi 『三国史記』5, a history book from 1145, in which geographical area names of the region are mentioned. It is unknown whether these geographical notations were made by Goguryeo people, or were taken over by the rulers from the indigenous language (Some theories say that the languages of Goguryeo and Silla were very close and the difference between them was only that of dialects). It is yet difficult to determine whether they are languages or dialects. Regarding this, it is interesting to observe that persons' names reflect the language differences more specifically. Since Goguryeo was located near Xuantu 玄菟 and Lelang 楽浪 districts/counties, Chinese characters and texts had been used from a relatively early stage (See Fig. 2).

\footnotetext{
${ }^{5}$ Samguk Sagi (Korean pronunciation: [s $\mathrm{s}^{\mathrm{h}}$ amgukssagi]; History of the Three Kingdoms) is a historical record of the Three Kingdoms of Korea:Goguryeo, Baekje and Silla. The Samguk Sagi is written in Classical Chinese. its compilation was by the government official and historian Kim Busik (金富軾) and a team of junior scholars and completed in 1145 . http://en.wikipedia.org/wiki/Samguk_Sagi (accessed January 5th, 2015).
} 


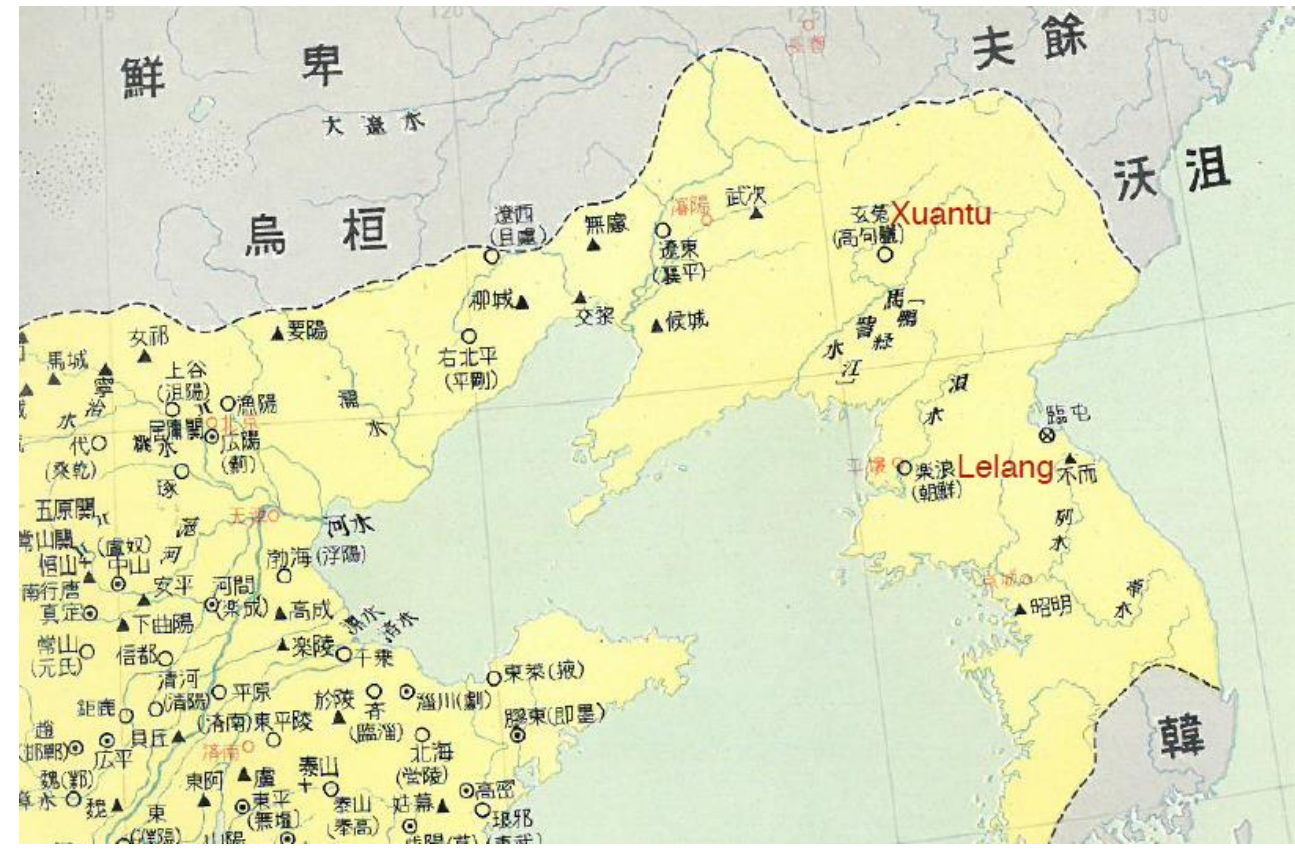

Figure 2: Goguryeo area.

The pronunciation of characters established in this area, as a window of Chinese culture in the ancient times, is the oldest layer of syllable sounds in the Korean Peninsula: these were soon brought to the Japanese archipelago, and today they are called ko'on 古 音 “old pronunciation” or kokan’on 古韓音 “old Korean pronunciation” because of their origin. Perhaps, the use of Chinese characters in Goguryeo spread also to Paekche, Silla, Gaya $^{6}$ (see Fig. 3), and established the use of characters, the primeval writing system in the Korean Peninsula.

Ko' on (the old pronunciation) derives from the syllables of Han Dynasty of China, and it reflects the transition from the ancient to medieval times in the Chinese phonological history. Syllables seen in "the inscriptions on the iron sword" unearthed in Inariyama Kofun Tumulus 稲荷山古墳鉄剣銘 (see Fig. 4) or Suiko ibun 推古遺文 ${ }^{7}$ are as follows: (Those that are the same as go'on 只音 [the $\mathrm{Wu}$ reading of Chinese characters, imported to Japan from the South part of China] are omitted.)

奇宜 ga 披pa 移余ya 獲wa 支 ki 至 $\mathrm{ti}$ 居kë 尼 ne

意o 垝ko 止 to 乃 no 富 pö 已yö 里 rö 乎wo

6 伽耶 Gaya (AD 42-532) was a Korean confederacy of territorial polities in the Nakdong River basin of southern Korea. It was later annexed by Silla, one of the Three Kingdoms of Korea. http://en.wikipedia.org/wiki/Gaya_confederacy (accessed January 5th, 2015).

${ }^{7}$ Suiko ibun 推古遺文、推古朝遺文 written materials from the period of A.C. 593 - 697, Emperors Suiko to Jitô. 


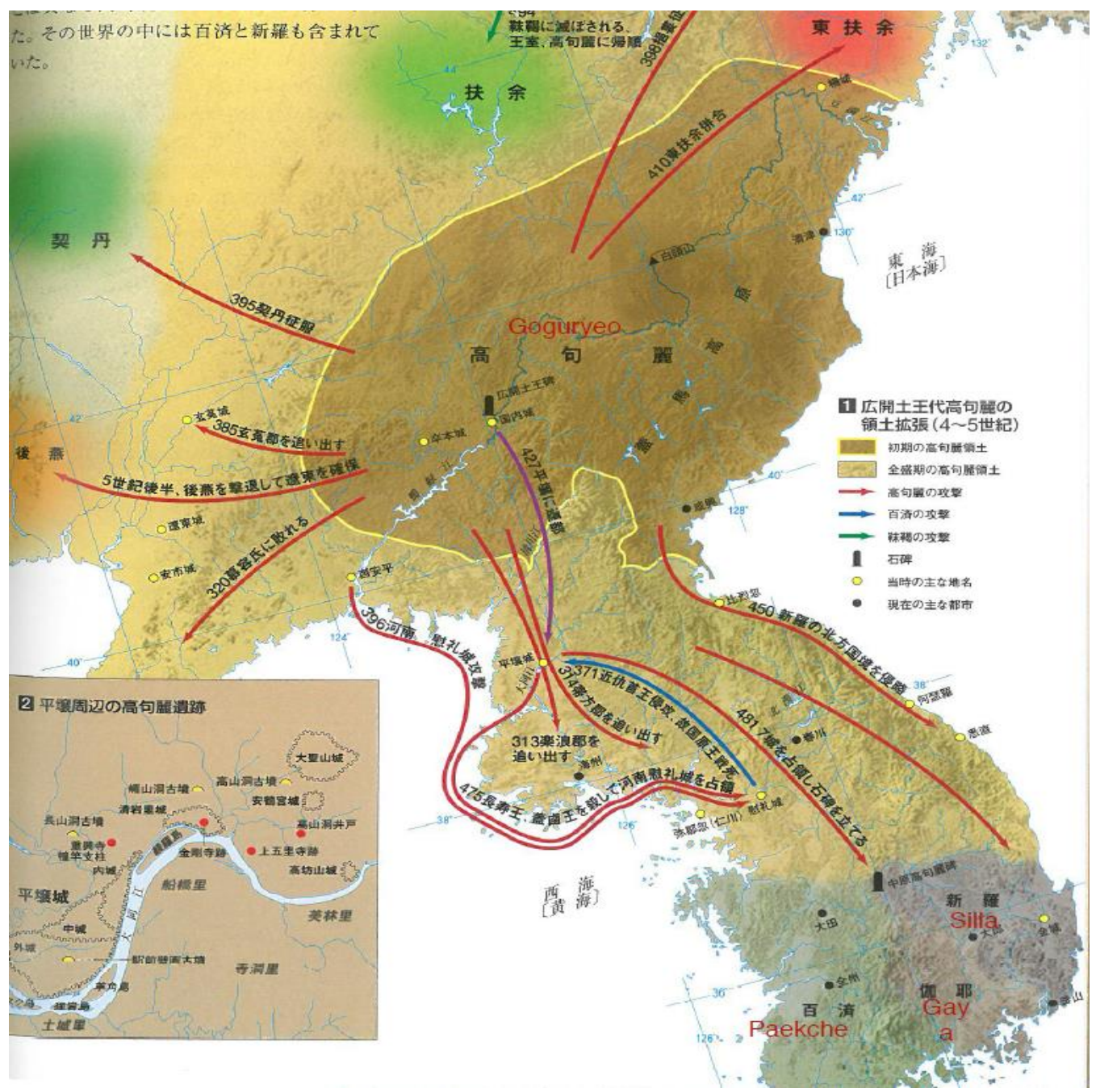

Figure 3: The area of Paekche, Silla and Gaya.

If we observe them from the viewpoint of Chinese phonological history, they seem to be based on some estimated era, namely, when the core vowel of the sounds 意 $\mathrm{o}$, 止 to, 已 yö, and 里 rö was ' $ə$ ', and when the core vowel of sounds 移 ya and 余 ya was 'a'.

In geographical names that can be seen in Korean ancient epigraphs and the geographical journals8 of Samguk Sagi, we can observe Chinese characters of ko'on 古 音 (old pronunciation), as mentioned earlier. (Referred to as Vol. 34 - 37, g. j. [geographical journals] 1- 4, etc. below.)

8 "Geographical journals", 地理志、지리지: Vol. 34-37 of Samguk Sagi. 


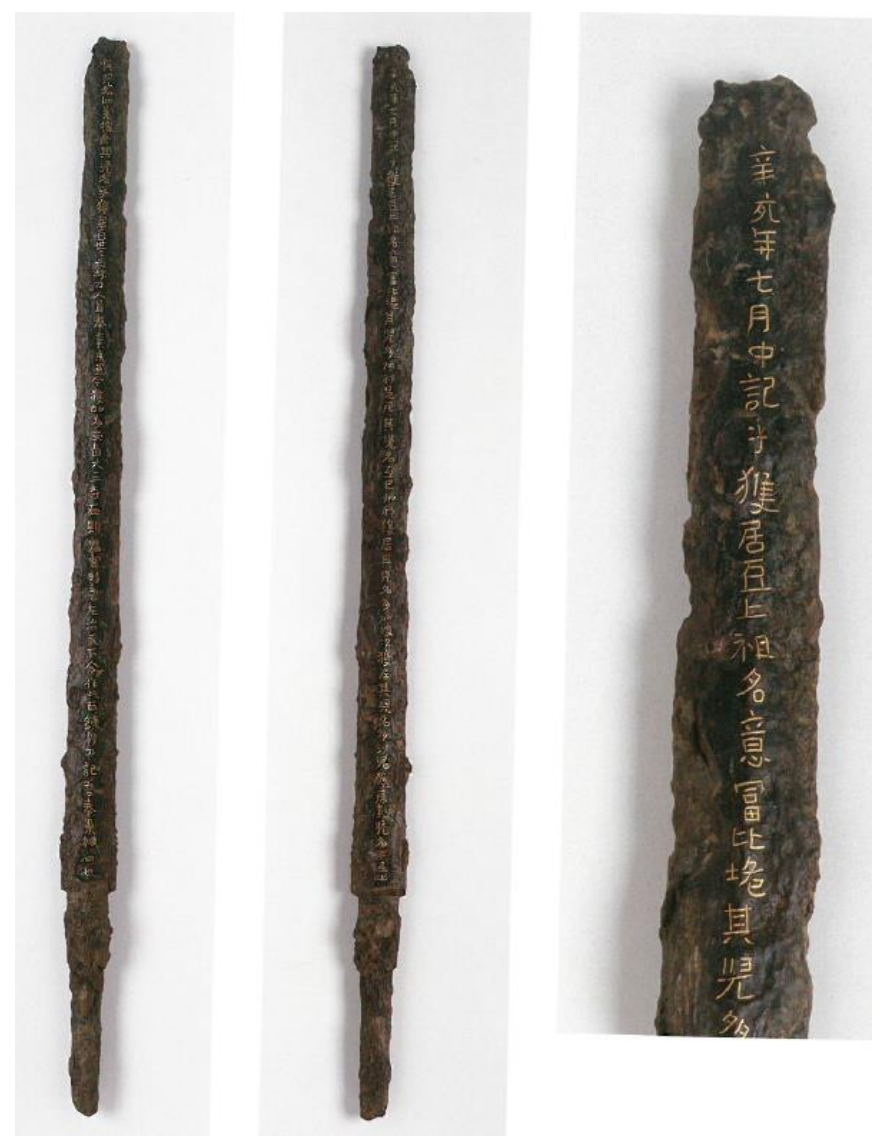

Figure 4: “The inscriptions on the iron sword” unearthed in Inariyama Kofun Tumulus 稲荷山 古墳鉄剣銘.

(1) 黄驍県、本高句麗骨乃厅県、景徳王改名、今黄驪県。(Vol. 35, g. j. 2)

황효현, 본고구려골내근현, 경덕왕개명, 금황려현.

hwanghyohyeon, bongoguryogollaegeunhyeon, gyeongdeokwanggaemyeong, geumhwangnyeohyeon. ${ }^{9}$

[Eng.] ${ }^{10}$ Kôjô prefecture was previously called XX (乃斤) prefecture in Goguryeo, and was renamed in the time of the King Gyeongdeok. Now ( $12^{\text {th }}$ century) it is called XX (黄驪) prefecture.

${ }^{9}$ For all notations of Korean pronunciation of Chinese characters in this article, the official romanization system of Korean language in today's South Korea is used. We are not able to exactly reconstruct the sounds from the 12th century, represented in the historical documents. For detailed transcription with corresponding phonetic alphabets, see Appendix at the end of the article.

${ }^{10}$ Geographical notations in Vol. 35 of Samguk Sagi have the same construction and therefore, the English translation is omitted except for examples (1) and (27). 
(2) 分津県、本高句麗乎唯押県、景徳王改名、今通津県。(Vol. 35, g. j. 2) 분진현, 본고구려호유압현, 경덕왕개명, 금통진현.

bunjinhyeon, bongoguryohoyuapyeon, gyeongdeokwanggaemyeong, geumtongjinhyeon.

(3) 声山県、本高句麗加支達県、景徳王改名、今汶山県。(Vol. 35, g. j. 2) 청산현, 본고구려가지달현, 경덕왕개명, 금문산현.

cheongsanhyeon, bongoguryogajidalhyeon, gyeongdeokwanggaemyeong, geummunsanhyeon.

(4) 至留県、本知留。(vol. 37, g. j. 4 百済・帯方州本竹軍城六県)

지류현, 본지류. (백제, 대방주본죽군성육현)

jiryuhyeon, bonjiryu. (baekje, daebangjubonjukgunseongyukhyeon)

Among characters used in Goguryeo's geographical notations, i. e. 波 pa, 也 ya, 於 $\mathrm{o}$, 知 ti, 古 $\mathrm{ko}$, 波 $\mathrm{pa}$, 於 $\mathrm{o}$, 知 $\mathrm{ti}$, 古 ko can be seen also in Suiko ibun, but not 意 and 移 or 余 for sounds'o' or 'ya'. From this fact, we may say that not only the sound-borrowing characters (音借字) from before the $4^{\text {th }}$ century, but also those of later periods exist together in the Goguryeo geographical notations.

Furthermore, even though it is unclear in which period the native semantic reading ( $k u n$ 訓) of Chinese characters was established in the Korean Peninsula, there is no doubt that it had been already used in the ancient Goguryeo.

For example, one notation example that can be seen is 珍, which is the same with the sound-borrowing character （音借字）突, the kun reading of $* t u r^{l 1}$.

(5) 馬突県 一云馬珍。(Vol. 37, g. j. 4 百済、馬霊県)

마돌현, 일운마진. (백제, 마령현)

madolhyeon, ilunmajin. (baekje,maryeonghyeon)

\section{The sound-borrowing characters in the geographical journals of Goguryeo and Paekche}

\subsection{Notations as Tungus Languages}

The characteristics of the languages of Guguryeo are unknown due to lack of materials. For now, based on the Tôiden story (東夷伝, "Stories on nations in the East")

${ }^{11}$ The sign * denotes the proto-form. 
in Gisho『魏書』(The Book of Wei), we consider them as Tungusic languages. According to Ikegami Jirô (1989), the typical examples of Tungusic languages can be seen as below:

(6) $\langle\operatorname{dream}($ n. $)\rangle$

tolkin (Evenki, Negital, Nanai)

tokki(n) (Orochi), tolĕin (Olcha)

tolěi(n-) (Uilta), torgin (Manchu written language)

$\langle\operatorname{dream}(\mathrm{v})$.

tojkišī (Solon), t’osi- (Udege)

From this, we can re-construct the proto-form *tolkin with the sound structure of CVCCVC. There is also the structure CVCCV such as *dolbo 〈night〉 in Evine and Evenki and dolbo in Nanai, and also the structure CVCVC such as * adin 〈wind (adan in Evine, adin in Evenki and Negital, adī in Solon, adi in Udege, adi(n) in Orochi, xədun in Nanai etc.). Therefore, it can be said that the syllables in proto-Tungus languages have the structure of CVC or CV (the word initial syllable can be a vowel without a consonant). Referring to this kind of phonological characteristics and Goguryeo's geographical notations, we may state the following:

\section{(i) There are long and short vowels.}

$/ \overline{\mathrm{a}} /$

（7）［立十守］城郡 一云加阿忽 (Vol. 37 g.j. 4, 高句麗・守城郡)

$$
\text { 수성군 일운가아홀 (고구려 - 수성군) }
$$

suseogun ilungaahol (goguryeo $•$ suseonggun)

忽 *kor can be seen as representing the meaning of 城〈stronghold (n.)〉, so [立 十守] corresponds to 加阿. From this orthography, it may be inferred as a long vowel, $/ \bar{a} /$. Furthermore, in the geographical notation Goryeo $\mathrm{Sa}^{12}$ 『高麗史』, in the 3rd section (東界条、동계조 donggyejo), we see:

\footnotetext{
${ }^{12}$ Goryeo Sa 高麗史 1451 . The Goryeosa or History of Goryeo is the principal surviving history of Korea's Goryeo Dynasty. Goryeo, also known as Koryŏ (Hangul: 고려; hanja: 高 麗 ; Korean pronunciation: [korj $]$; 918-1392), was a Korean dynasty established in 918 by King Taejo. http://en.wikipedia.org/wiki/Goryeosa, http://en.wikipedia.org/wiki/Goryeo (accessed January 5th, 2015).
} 
(8) 杆城県本高句麗 [立十守 $]$ 城郡 一云加羅忽

\section{간성현본고구려 수성군 일운가라홀}

ganseonghyeongoguryeo suseonggun ilungarahol

【additional reference】辺 - 鄙 $\square$ (Hunmongjahoe 訓蒙字会 ${ }^{13}$ Vol. $2,4 \mathrm{v}$. according to Eisanhon（频崠） as below）

$/ \overline{\mathbf{o}} /$

(9) 獐塞県 一云古所於。 (Vol. 37, g.j. 4 高句麗・獐塞県)

장새현 일운고소어. (고구려 - 장새현)

jangsaehyeon ilungosoeo (goguryeo $\cdot$ jangsaehyeon)

Considering how it relates to the following examples, it can be said that 獐 is equivalent to 古.

(10) 獐項口県 一云古斯也古次 (Vol. 37, g. j. 4 高句麗・獐口郡)

$$
\text { 장항구현, 일운고사야고차 (고구려 - 장구현) }
$$

janghangguhyeon, ilungosayagocha (goguryeo $•$ jangguhyeon)

Therefore, it can be said that 所於 corresponds to 塞, and 於 indicates the long vowel/ $\overline{\mathrm{o}} /$.

$/ 1 /$

(11) 解礼県、本皆利伊。(Vol. 37, g. j. 4 百済・支潯習九県)

해례현, 본개리이. (백제·지심습구현)

haeryehyeon, bongaerii. (baekje $\cdot$ jisimseupguhyeon)

New names were given with corresponding sound representations of 解=皆 and 礼 $=$ 利伊, and we may guess that the long vowel in 利伊 $* r \bar{l}$ changed to a diphthong (double vowel) *ei.

【additional reference】 ' $r$ ' or ' 1 ' of Goguryeo and Silla languages are represented by ' $r$ ' only.

${ }^{13}$ Hunmongjahoe 訓蒙字会, a textbook of Chinese characters in Korea, 1527. 
(ii) There are double consonants.

(12) 深川郡 一云伏斯買。(Vol. 37, g. j. 4 高句麗・浚水県)

심천군 일운복사매. (고구려· 준수현)

simcheongun ilunboksamae. (goguryeo $•$ junsuhyeon)

If 川 is equivalent to 買, then the relation 深=伏斯 is also true. If this is a syllabic notation, 伏 has a 'p'entering tone (入声) ${ }^{14}$, so 伏斯 should read *puksi or *puks-, an exceptional infix of a double consonant.

(13) 峯城県、本高句麗述爾忽県、景徳王改名、今因之。(Vol. 35, g. j. 2)

봉성현, 본고구려술이홀현, 경덕왕개명, 금인지.

bongseonghyeon, bongoguryeosuliholhyeon, gyeongdeokwanggaemyeong, geuminji.

(14) 述爾忽県、一云首泥忽。(Vol. 37, g. j. 4)

술이홀현, 일운수니홀.

suliholhyeon, ilunsunihol.

【cf.】屑夫婁城 本肖利巴梨忽。(Vol. 37, g. j. 4 高句麗・鴨緑江 以北) 설부루성 본초리피리홀. (고구려·압록강이북)

seolburuseong bonchoripirihol. (goguryeo $\cdot$ amnokgangibuk)

Since 城 is equivalent to 忽, and also by considering the relation between 峯二述 爾 and 述爾＝首泥，and the exchange between 't' entering tone（入声） and 'r' of 述, we can assume that 述爾 is a double consonant 'rn', as in *surn- (according to Lee GiMun 1975, 述爾 [首泥] coincides with sunirk 嶺 of the medieval Korean). As for the exchange of the coda（終声 the closing consonant） ' $t$ ' and ' $r$ ', the example with 勿 of the medieval Korean may be referred to.

(15) 徳水県、本高句麗徳勿県、景徳王改名、今因之。(Vol. 35, g. j. 2)

덕수현, 본고구려덕물현, 경덕왕개명, 금인지.

deoksuhyeon, bongoguryeodeongmulhyeon, gyeongdeokwanggaemyeong, geuminji.

\footnotetext{
${ }^{14}$ Entering tone or a checked tone: a syllable that ends in a stop consonant, such as $\mathrm{p}, \mathrm{t}, \mathrm{k}$, or glottal stop. http://en.wikipedia.org/wiki/Checked_tone, accessed January 20, 2015.
} 
It can be assumed that the ' $t$ '-entering tone（入声） of 勿 was pronounced as *mor.

(iii) The last sound of the syllable is either a vowel, 'n', or ' $r$ '.

/-n/

(16) 水谷城県 一云買旦忽。(Vol. 37, g.j. 4 高句麗・檀渓県)

수곡성현, 일운매단홀. (고구려 - 단부현)

sugokseonghyeon, ilunmaedanhol. (goguryeo $\cdot$ danbuhyeon)

(17) 於支亘 一云翼谷。(Vol. 37, g. j. 4 高句麗・翊谿県)

어지탄 일운익곡. (고구려·익계현)

eojitan ilunikgok. (goguryeo $\cdot$ ikgyehyeon)

旦 and 吞, *tan or *ton, indicate the meaning of 谷 〈valley〉.

/-r/

(18) 沙川県、本高句麗内乙買県、景徳王改名、今因之。(Vol. 35, g. j. 2)

사천현, 본고구려내을매현, 경덕왕개명, 금인지.

sacheonhyeon, bongoguryonaeeulmaehyeon, gyeongdeokwanggaemyeong, geuminji.

(19) 伊川県、本高句麗伊珍買県、景徳王改名、今因之。(Vol. 35, g. j. 2)

이천현, 본고구려이진매현, 경덕왕개명, 금인지.

icheonhyeon, bongoguryoijinmaehyeon, gyeongdeokwanggaemyeong, geuminji.

If 川 corresponds to 買, then the following relations are also true: 沙=内乙, 伊= 伊珍. Both 内乙 *nair and 伊珍 *itur end with the sound ' $r$ '. The syllable 珍 mentioned above indicates *tur.

(20) 馬突県 一云馬珍。 (vol. 37, g. j. 4 百済・馬霊県)

마돌현 일운마진. (백제·마령현)

madolhyeon ilunmajin. (baekje $\cdot$ maryeonghyeon )

However, there are some examples of other monosyllables ending in '-m' or '-k'. 
(21) 高木根県 一云達乙斬。(Vol. 37, g. j. 4 高句麗・喬桐県)

고목근현 일운달을참. (고구려 - 교동현)

gomokgeunhyeon ilundaleulcham. (goguryeo $\cdot$ gyodonghyeon)

(22) 楊根県 一云去斯斬。(Vol. 37, g. j. 4 高句麗・浜陽県)

양근현 일운거사참. (고구려 - 빈양현)

yangeunhyeon ilungeosacham. (goguryeo $\cdot$ binyanghyeon)

斬 is estimated to have had a sound similar to *cam, and with the coda '-m', it is possible that the word meaning 根 〈root〉 had an 'm' at the end of the syllable.

(23) 功木達県、一云熊「門十人」山。(Vol. 37, g. j. 4 高句麗・功城県)

공목달현. 일운웅산. (고구려·공성현)

gongmokdalhyeon, ilununghoeksan. (goguryeo $\cdot$ gongseonghyeon)

In the example above 達 corresponds to 山, therefore we can assume the relationship 功木 =熊. In Hunmongjahoe, there is also 熊 kom (上 10r.) which is related to the medieval Korean language (Lee Gi-Mun 1975). That is, 熊 is the kun reading (the native or local reading), and it is assumed to be equivalent to 木 for the coda ' $k$ '. However, it is unclear whether it was originally from the Goguryeo language or not.

In addition, I would raise two additional points as characteristics of proto-Tungus syllables:

(iv) There is no double consonant at the beginning or the end of a syllable.

(v) R-sound does not occur at the beginning of a syllable.

The following syllable-initial ' $r$ ' in 栗木 is typical for Chinese classics.

(24) 栗津郡、本高句麗栗木郡、景徳王改名、今菓州。(Vol. 35, g. j. 2)

율진군, 본고구려율목군, 경덕왕개명, 금과주.

yuljingun, bongoguryeoyulmokgun, gyeongdeokwanggaemyeong, geumgwaju.

Though it is obviously difficult to clarify the Goguryeo language due to lack of materials, it can be said that no big contradictions may be found with the present Tungus languages. 


\subsection{Notations departing from the syllabic structure}

To begin with, it is often difficult to indicate sounds of reconstructed proto-Tungus words by Chinese characters. For example, the proto-word for 〈drip $\rangle{ }^{*}$ sabda- (xabdain Even, sabda- in Nanai, Negital, Orchai, Uilta and Manchu written languages), 'bd' in the word, particularly the final consonant of the first syllable ' $b$ ' has no corresponding example among Chinese characters at that time. The syllable-ending sounds in Middle Chinese 中古音 are as follows:

Stops（入声韻尾） …..p $\mathrm{t} \quad \mathrm{k}$

Nasals (撥韻尾)......m n $\mathrm{n} \quad$;

Sub-vowels（副母音）.....i u

The following examples show another difficult situation:

(25) 横川県 一云於斯買。(Vol. 37, g.j. 4 高句麗・横川県)

횡(광)천현 일운어사매. (권 37 지리지 4 고구려 · 횡(광)천현)

hoeng (gwang) cheonhyeon iluneosamae. (goguryeo hoeng (gwang)

cheonhyeon)

(26) 於斯内県 一云斧猿。(Vol. 37, g. j. 4 高句麗 - 広平県)

어사내현 일운부양. (고구려·광평현)

eosanaehyeon ilunbuyang. (goguryeo $・$ gwangpyeonghyeon)

In both examples 於斯 corresponds to 横 and 斧, and is estimated to be the word * $\partial s$ (according to Lee Gi-Mun 1975) and it coincides with $\partial s$ 横 of middle Korean. Apart from the question whether the original word belongs to Tungus languages or not, the notation of final consonant 's' cannot be processed by any Chinese character. Therefore, it needed a special letter to express the syllable-ending consonant, in this case 斯.

\section{Various usages of sound-borrowing characters}

\subsection{The use of Japanese man'yôgana 万葉仮名 in 5th century}

In "the inscribed iron sword unearthed" in Inariyama Kofun Tumulus (see Fig. 5), the use of man'yôgana (Japanese sound-borrowing letters) can be seen as follows:

(i) Zen'on-gana 全音仮名: A Chinese character without a coda becomes the notion of one Japanese syllable.

[Example ] 乎獲居臣...乎 and 居 are equivalent to the syllables of 'wo' and 'kë'. 
(ii) Rengô-gana 連合仮名: The condition of a foregoing coda and the following onset.

[Example] 乎獲居臣......the syllable-ending of 'wak' 獲 is used to be doubled with the ' $\mathrm{k}$ ' -onset and becomes only one ' $\mathrm{k}$ '.

(iii) Nigô-gana 二合仮名: The notion of two syllables in Japanese by one Chinese character.

\section{[Example ] 多加利足尼......足 ‘suk' becomes two syllables 'suku' in Japanese.}

In addition, the following example is also shown as ryaku'on-gana (略音仮名 omission of a coda).

[Example] 其児名半马比...... 'n' of 半 'pan' is omitted.

The last example is to record the sound-chain /hadehi/: the coda ' $n$ ' in 半 shows that the following syllable is voiced, i.e. 'nde' 互, therefore it can be classified as a rengô- gana. We must note that genuine examples of kun-gana ${ }^{15}$ and ryaku'on-gana certainly existed in the 7 th century.
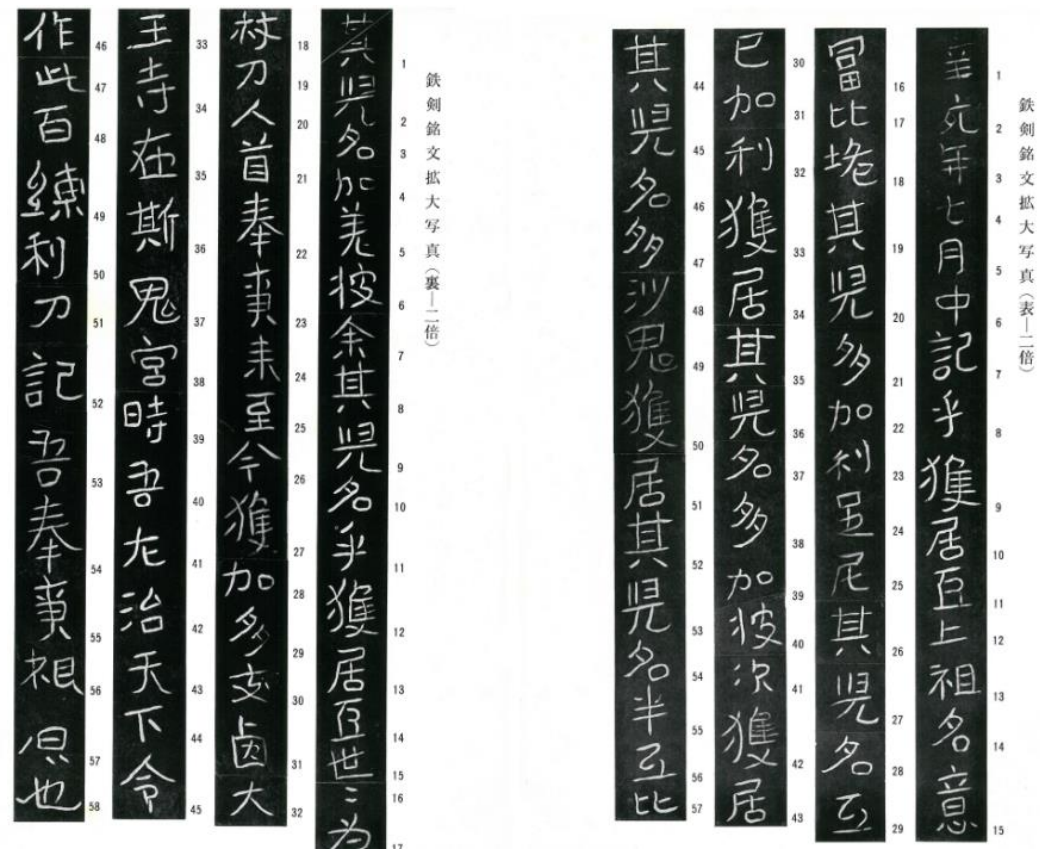

Figure 5: The use of man'yôgana in Inariyama Kofun Tumulus.

\footnotetext{
${ }^{15}$ Kun-gana 訓仮名 One kind of manyô-gana. The semantic reading of a character in Japanese is alotted to Japanese syllables, regardless of its meaning. E.g. ya ma to 「八間跡」. http://www.weblio.jp/content/\%E8\%A8\%93\%E4\%BB\%AE\%E5\%90\%8D (accessed Jan. 19, 2015).
} 


\subsection{History of man'yôgana}

In the geographical notation of Goguryeo, zen'on-gana and rengô-gana were used very widely.

(27) 黒壌郡(一云黄壌郡)、本高句麗今勿奴郡、景徳王改名、今鎮州。(Vol. 35, g. j. 2)

흑양군(일운황양군), 본고구려금물노군, 경덕왕개명, 금진주.

heukyanggun (ilunhwanggun), bongoguryeo geummulnogun,

gyeongdeokwang gaemyeong, geumjinju.

[Eng.] Kokujô county (named also Ojô county) was previously called YY (勿奴) county, and was renamed in the time of the King Gyeongdeok. Now (12 $2^{\text {th }}$ century) it is called ZZ (鎮州).

(28) 今勿内郡、一云万驽。 (Vol. 37, g. j. 4 高句麗 ・黑壤郡)

금물내군, 일운만노. (고구려·흑양군)

geummullaegun, ilunmanno. (goguryeo • heukyanggun)

今勿 coincides with the middle Korean 黒 kamir (Hunmongjahoe 訓蒙字会 中 $14 \mathrm{v}$ ), and therefore, “今 *kam+勿 *muət” is a use of rengô-gana. Uses of nigh-gana are also present:

(29) 峯城県、本高句麗述爾忽県、景徳王改名、今因之。(Vol. 35, g. j. 2 )

봉성현, 본고구려술이홀현, 경덕왕개명, 금인지.

bongseohyeon, bongoguryeosuliholhyeon, gyeongdeokwanggaemyeong, geuminji.

(30) 述爾忽県、一云首泥忽。(Vol. 37, g. j. 4)

술이홀현, 일운수니홀.

suliholhyeon, ilunsunihol.

As already mentioned above, the relationship 峯=述爾 $=$ 首泥 holds true, but the next example shows the equivalence of 峯=述.

(31) 陰峯県(一云陰岑)、本百済牙述県、景徳王改名、今牙州。(Vol. 36, g. j.3)

음봉현(일운음잠), 본백제아술현, 경덕왕개명, 금아주.

eumbonghyeon (iluneumjam), bonbaekjeasulhyeon, gyeongdeokwang gaemyeong, geumaju. 
牙 is 'om' in middle Korean (Hunmongjahoe Vol. 1, 13v.), and was most probably used to substitute 陰 im (Hunmongjahoe Vol. 1, 1r.). Since 述 may be interpreted to have meant a sound-borrowing character both for 述爾 as well as 首泥, it can be called nigô-gana as well. (Same as 比 of 甲比 $(=\square)$, to be described later.)

On the other hand, the example of kun-gana 訓仮名 that has already been confirmed is 珍*tor, or in the georaphical notation of Silla's, the following ryaku'on-gana usage can be seen.

$$
\begin{aligned}
& \text { 多仁県、本達己県 或云多己、景徳王改名、今因之。(Vol. 34, g.j. 1) } \\
& \text { 다인현, 본달기현 혹운다기, 경덕왕개명, 금인지. }
\end{aligned}
$$

dainhyeon, bondalgihyeon, hokundagi, gyeongdeokwanggaemyeong, geuminji.

己 was revised from 已 in Tôyô bunko 東洋文庫 ${ }^{16}$, however it was referred as 多 *ta, the omitted form of the coda ' $r$ ' of 達*tar.

（33）日奚谷県、本熱兮県、或云埿兮、景徳王改名、今未詳。(Vo. 34, geograph. notation 1)

일계현, 본열혜현,혹운니혜, 경덕왕개명, 금미상.

ilgyeohyeon, bonyeolhyehyeon, hokunnihye, gyeongdeokwanggaemyeong, geummisang.

Same as the example above, that 泥*ne is used to be 熱 *ner, means that the ' $\mathrm{r}$ ' is omitted. However, if we compare the usage of kun-gana and ryaku'on-gana with Zen'on-gana (全音仮名) and Rengo-gana（連合仮名） it can be seen as the posterity of those forms.

\subsection{The usage of borrowed characters in the Three-Kindoms Period}

The syllable structures of Goguryeo, Paekche and Silla languages, observed as Tungus languages, are significantly different from the ancient Japanese syllabic structure, the latter consisting of one consonant and one vowel. Therefore, the former languages developed special uses of characters to notate syllable-ending consonants.

\footnotetext{
${ }^{16}$ The Tōyō Bunko (東洋文庫), or "Oriental Library", is Japan's largest Asian studies library and one of the world's five largest.

http://en.wikipedia.org/wiki/T\%C5\%8Dy\%C5\%8D_Bunko, accessed January 19, 2015.
} 


\subsubsection{The notation of final consonants (coda)}

There are many references to the use of sound-borrowing characters for syllableendings in the geographical notation of Samguk Sagi. The character 戸 was already seen in Goguryeo, as a character for the final consonant ' $r$ '.

(34) 有隣郡、本高句麗于卫郡、景徳王改名、今礼州。(Vol. 35, geographical notation 2

유린군, 본고구려우시군, 경덕왕개명, 금예주.

yuringun, bongoguryeousigun, gyeongdeokwanggaemyeong, geumyeju.

(35) 武霊郡、本百済武已伊郡、景徳王改名、今因之。（Vol. 36, geographical notation 3)

무령군, 본백제무시이군, 경덕왕개명, 금인지.

muryeonggun, bonbaekjemusiigun, gyeongdeokwanggaemyeong, geuminji.

The former 于尸 is *ur, therefore it can be seen as a place with a similar sound as 有隣. The latter is assumed to be *ri, therefore it probably was renamed to be liey ( 霊) in middle Chinese.

(36) 安賢郡 本阿已兮県 一云阿己兮、景徳王改名、今安定県。(Vol. 34, g. j.1) 안현군 본아시혜현 일운아을혜, 경덕왕개명, 금안정현.

anhyeongun bonasihyehyein ilunaeulhye, gyeongdeokwanggaemyeong, geumanjeonghyeon.

Also in case of Silla's geographical notations, the correspondence $=乙$ was known, and it can be assumed that *ar was replaced by *an (安).

On the other hand, if we see the following example of 知 $=乙$, we can see that the syllable-ending consonant is neutralized as *katna - *karna.

(37) 加知奈 一云加乙乃。(Vol. 37, g. j. 4 百済・市津県)

가지내 일운가을내. (백제·시진현)

gajinae ilungaeulnae. (baekje $\cdot$ sijinhyeon)

Meanwhile, if we see the character 音 in the word 夜音 (in hyangga ${ }^{17}$ ), it is a sound-borrowing character to notate the final consonant ' $\mathrm{m}$ ' in the word meaning night〉, the specific noun 夜 /pam/ 〈night〉 (Hunmongjahoe 訓蒙字会 Vol.1, 1r.).

\footnotetext{
${ }^{17}$ Hyangga 향가 (鄉歌) were poems written in a native writing system, composed in the Three Kingdoms, Unified Silla and early Goryeo periods of Korean history. http://en.wikipedia.org/wiki/Hyangga, accessed january 19, 2015.
} 


$$
\mathrm{pam}=\text { 夜 } \mathrm{pa}+\text { 音 } \mathrm{m}=\text { 夜音 }
$$

This kind of usage was already seen in the Goguryeo geographical notations:

(38) 穴城 本甲忽。(Vol. 37, g. j. 4 高句麗・鴨緑江以北)

혈성 본갑홀. (고구려·압록강이북)

hyeolseong bongapol. (goguryeo • amnokgangibuk)

(39) 穴口郡 一云甲比古次。(Vol. 37, g. j. 4 高句麗・海口郡)

혈구군 일운갑비고차. (고구려 · 해구군)

hyeolgugun ilungapbigocha. (goguryeo • haegugun)

According to these notations, the relationship is 穴=甲＝甲比. 甲 can be seen as *kap, therefore 比 is understood as the final sound ' $\mathrm{p}$ ' in 甲比. (However, there is a possibility that some of this kind of syllable-ending borrowed characters were accompanied by a vowel.)

(40) 習奚谷県、本高句麗習比谷県、景徳王改名、今㰸谷県。(Vol. 35, g. j. 2)

$$
\text { 습계현, 본고구려습비곡현, 경덕왕개명, 금흡곡현. }
$$

seupgyhyeon,bongoguryeoseupbigokyeon,gyeongdeokwanggaemyeong, geumheupgokyeon.

The character 習 above can be seen as an entering tone with a 'p' that is written as 比.

(41) 高烽県、本高句麗達乙省県、景徳王改名、今因之。(Vol. 35, g. j. 2)

고봉현, 본고구려달을성현, 경덕왕개명, 금인지.

gobonghyeon, bongoguryeodaleulseonghyeon, gyeongdeokwanggaemyeong, geuminji.

(42) 高木根県 一云達乙斬。（vol. 37 g.j. 4 高句麗・喬桐県）

고목근현, 일운달을참. (고구려 - 교동현)

gomokgeunhyeon, ilundaleulcham. (goguryeo $\cdot$ gyodonghyeon)

【refer to】楊根県 一云去斯斬。(Vol. 76, g.j. 4 高句麗・浜陽県) 양근현 일운거사참. (고구려 · 빈양현)

yanggeunhyeon ilungeosacham. (goguryeo • binyanghyeon) 
高 coincides with 達乙, and we can assume with no doubt that the character 乙 is used for the final consonant ' $r$ ' in *'tar 達.

In geographical notations of Paekche, it is possible that the character 只 as shown below represents the final consonant ' $\mathrm{k}$ ' of 力 and 禄.

(43) 沃野県、本百済所力只県、景徳王改名、今因之。(Vol. 36, g. j. 3)

옥야현, 본백제소력지현, 경덕왕개명, 금인지.

okyahyeon, bonbaekjesoryeokjihyeon, gyeongdeokwanggaemyeong, geuminji.

(44) 塩海県、本百済古禄只県、景徳王改名、今臨淄県。(Vol. 36, g. j. 3 )

염해현, 본백제록지현, 경덕왕개명, 금임지현.

yeomhaehyeon, bonbaekjerokjihyeon, gyeongdeokwanggaemyeong,

geumimjihyeon.

This kind of notation is found also in Man'yôshu ${ }^{18}$ in the following variations:

(i) Using kun-gana for the final syllable in a word of kun-doku reading.

(45) 隠口乃長谷小国夜延為吾志皇寸导 (Man’yôshu Vol. 13: 3312)

sesu aga sumero ki yo

(46)

古部念爾 (Vol. 1: 46)

inisipe omofuni

Characters 寸 and 部 in 天皇寸 and 古部 respectively are supposed to define the sounds as sumeroki, and inisipe, and therefore these characters correspond to the okurigana ${ }^{19}$ in later materials of kunten (訓点資料, the guiding marks for rendering Chinese into Japanese).

\footnotetext{
${ }^{18}$ The Man'yōshū (万葉集, literally "Collection of Ten Thousand Leaves") is the oldest existing collection of Japanese poetry, compiled sometime after 759 AD during the Nara period. http://en.wikipedia.org/wiki/Man\%27y\%C5\%8Dsh\%C5\%AB, accessed January 19, 2015.

${ }^{19}$ Okurigana (送り仮名 accompanying letters) are kana suffixes following kanji stems in Japanese written words. http://en.wikipedia.org/wiki/Okurigana, accessed January 19, 2015.
} 
(ii) Writing nigô-gana's final consonant by on-gana ${ }^{20}$

(47) 百式紀乃大宮人之飽田津尔 (Man'yôshu Vol. 3: 323) momosiki

The Character 式 can be used as a nigô-gana 百式乃 (Man'yôshu Vol. 3: 260) as well, but 紀 is added here to define that 'siki' is 'siki2" 21.

The former example is similar to the use in hyangga, and the latter is similar to the geographical notation of Goguryeo. However, it is unclear whether these were directly influenced by the system of notation practiced in the Korean Peninsula.

\subsubsection{The final consonant ' $r$ ' in rengô-gana}

Notations 古次 and 忽次 in the following examples seem to stand for 口. (48a) 穴旦郡 一云甲比古次。(Vol. 37, g. j. 4 高句麗 - 海口郡)

혈구군 일운갑비고차. (고구려 - 해구군)

hyeolgugun ilungapbigocha. (goguryeo • haegugun)

(48b) 楊므 郡 一云要隠忽次。(Vol. 37, g. j. 4 高句麗・楊麓郡)

양구군 일운요은홀차. (고구려·양록군)

yanggugun ilunyoeunholcha. (goguryeo $•$ yangrokgun)

(48c) 獐項口県 一云古斯也忽次。(Vol. 37, g. j. 4 高句麗・獐口郡)

장항구현 일운고사야홀차. (고구려·장구군)

janghangguhyeon ilungosayaholcha. (goguryeo $\cdot$ janggugun)

If we look at the examples above, we can understand the relationship 口二古次= 忽次, where 古次 has the same sound as 忽次. Therefore, 忽 stands for the sound *kor, of which the syllable-ending sound is $r$ : this is a rengô-gana followed by the sound 'c' of 次, which corresponds to the reading *koc.

20 音仮名 A kind of manyôgana. Regardless of the original meaning of Chinese characters, the sound of each character is alotted to Japanese syllables, e.g. 「也末」 for “yama (mountain)", 「比登」 for "hito (man)".

http://www.weblio.jp/content/\%E9\%9F\%B3\%E4\%BB\%AE\%E5\%90\%8D (accessed January 19, 2015).

${ }^{21}$ Type B, 乙. 
Here, we can see the final consonant ' $r$ ' of a rengô-gana. In the $8^{\text {th }}$ century. There was the same tendency in renaming *ac with *ar(at).

(49) 圧海郡、本百済阿次山県、景徳王改名、今因之。(Vol. 36, g. j. 3)

압해군, 본백제아차산현, 경덕왕개명, 금인지.

apaegun, bonbaekjeachasanhyeon, gyeongdeokwanggaemyeong, geuminji.

On the other hand, the character 口 may stand for 串 *kwan as in the following.

(50) 泉井口県、一云於乙買串。(Vol. 37, g. j. 4 高句麗・交河郡)

천정구현, 일운어을매곷(관). (고구려·교하군)

cheonjeongguhyeon,iluneoeulmaegot (gwan). (goguryeo $・$ gyohagun)

Based on the relationship 泉=於乙 (Nihon shoki ${ }^{22}$ Vol. 24 「伊梨柯須弥」=泉 蓋蘇文) and 井=買 (水=買), 口 corresponds to 串, and here we may be observing the neutralization of $\mathrm{c} / \mathrm{n}$ in the final consonant. Moreover, we can see the correspondence 乙 $=$ 爾 in the following example.

(51) 内乙買 一云内爾米。(Vol. 37, g.j. 4)

내을매 일운내이미.

neeulmae ilunneimi.

By seeing the $r / n$ neutralized, and since the entering tone ' $t$ ' can be pronounced as ' $\mathrm{r}$ ', consonants ' $\mathrm{r}-\mathrm{n}-\mathrm{t}-\mathrm{c}$ ' are neutralized except for the onset. As it was mentioned above, '-n' and '-r' can be seen in the final consonant in Tungus languages, while '-r' does not exist as a final consonant in middle Chinese. In ancient Chinese 上古音, $*_{-} r$ may be expected, however it is difficult to say that in geographical notations, the neutralization of syllable-endings $\mathrm{t}$ and $\mathrm{r}$ is caused by the $*_{-} r$. It is reasonable to say that in Goguryeo, the final consonant ' $r$ ' was replaced by the most similar sound ' $t$ '.

\subsection{Usages commonly seen in the ancient Japanese}

\subsubsection{Glottal sounds}

As mentioned above that there is the correspondence 古次=忽次, 古 has the onset consonant /k/, and 忽 the onset consonant /x/ in middle Chinese. In Gisho Toiden, we see:

${ }^{22}$ The Nihon Shoki 日本書紀, sometimes translated as The Chronicles of Japan, is the second oldest book of classical Japanese history, finished in 720 .

http://en.wikipedia.org/wiki/Nihon_Shoki, accessed January 19, 2015. 
(52) 溝漊者句麗名城也

\section{구루자구여명성야}

gurujagu yeomyeongseongya

Here, 溝 is assumed to have the onset consonant $/ \mathrm{k} /$, and corresponds to the onset consonant $/ \mathrm{x} /$ in middle Chinese.

However, in Tungus languages, / $\mathrm{x} /$ is assumed to have appeared only as an onset, therefore, we may say that $/ \mathrm{x} /$ was neutralized with $/ \mathrm{k} /$ in other positions. The representation 卑弥呼 in Gisho Tôiden is the notation of "Pimiko", so /x/ was used for Japanese $/ \mathrm{k} /$. There is no doubt that there existed speakers of Tungus languages in the work of Chinese history editing. In relation to this, the example in case of 加兮 that corresponds to 客 and 各, they probably had the same final consonant ' $\mathrm{k}$ ' in 兮 (onset /xh-/ followed by /-i/).

(53a) 客連郡 客一作各、一云加合牙。(Vol. 37, g. j. 4 高句麗・連城郡)

객련군 객일작각, 일운가혜아. (고구려·연성군)

gaengnyeongun gekiljakgak, ilungahyea. (goguryeo $\cdot$ yeonseonggun)

Other examples of an onset are as follows.

(53b) 休壤郡 一云金悩。(Vol. 37, g. j. 4 高句麗・金壌郡)

휴양군 일운금뇌. (고구려·금양군)

hyuyanggun ilungeumnoe. (goguryeo $\cdot$ geumyanggun)

(53c) 金池県 本百済仇知県、景徳王改名、今全義県。(Vol. 36, g. j. 3) 금지현 본백제구지현, 경덕왕개명, 금전의현.

Geumjihyeon bonbaekjegujihyeon, gyeongdeokwanggaemyeong, geumjeonuihyeon.

(53d) 金溝県、本百済仇知只山県、景徳王改名、今因之。(Vol. 36, g. j. 3) 금구현, 본백제구지지산현, 경덕왕개명, 금인지.

geumguhyeon, bonbaekjegujijisanhyeon, gyeongdeokwanggaemyeong, geuminji.

For the character 金, in Goguryeo it becomes 休 (onset /x-/ followed by /-on/), while in Paekche it corresponds to 仇 or 仇知 (/kh-/ and /-on/). This kind of confusing system of onset also had the same phenomena of ' $\mathrm{h} \sim \mathrm{k}$ ' neutralization which happened in 
Japanese in the 7th century. The next one is 兮, which is used in the same value as 衣 (the onset / / /) and could be 波衣 - 破兮 = 峴 as well.

(53e) 平珍峴県 一云平珍波衣(Vol. 37,g.j. 4 高句麗・偏検県)

평진현현 일운평진파의 (고구려·편험(嶮)현)

pyeongjinhyeonhyeon ilunpyeongjinpaui (goguryeo • pyeonheom (嶮) hyeon)

(53f) 三峴県 一云密波兮(Vol. 37,g.j. 4 高句麗・ 三嶺県)

삼현현, 일운밀파혜(고구려·삼령현)

samhyeonhyeon, ilunmilpahye. (goguryeo $\cdot$ samnyeohyeon)

兮* xe has no difference with ' $\mathrm{e}$ ' in the middle of the word.

\subsubsection{Nasal sounds}

Examples from notations in Silla are as follows.

(59) 軍威県、本奴同覔県、或云如豆硯、景徳王改名、今因之。(Vol. 34, geographical 1)

군위현, 본노동멱현, 혹운여두멱, 경덕왕개명, 금인지.

gunwihyeon, bonnodongmyeokeon, hokunyeodymyeok, gyeongdeokwang gaemyeong, geuminji.

Aside from 奴 /d/ and 如 /nz/，同 is *don(定母東韻) that has been neutralized as ' $-\eta$ ' and ' $-u$ ' of *dou. It is shown that the phenomena of $-\eta>-u$ happened in the lat Heian period in Japan. There is a similar case that the character 豆 could be replaced by 同 which happened in the era of King Gyeongdeok (景徳王).

(60) 国福県、本百済豆夫只県、景徳王改名、今因之。（Vol. 36, g. j. 3)

동복현, 본백제두부지현, 경덕왕개명, 금인지.

dongbokeon, bonbaekjedubujihyeon, gyeongdeokwanggaemyeong, geuminji.

只 is a ko'on (古音) of ' $k i$ ', and the above representation 夫只 is replaced by 福 as a nigô-gana.

Moreover, in the geographical notations of Goguryoe, some examples of ' $y$ ' and ' $m$ ' can be seen as follows. 
(61) 陰城県、本高句麗仍忽県、景徳王改名、今因之。（Vol. 35, g. j. 2) 음성현, 본고구려잉홀현, 경덕왕개명, 금인지.

eumseonghyeon, bongoguryeoingholhyeon, gyeongdeokwanggaemyeong, geuminji.

(62) 陰竹県、本高句麗奴音竹県、景徳王改名、今因之。（Vol. 35, g. j. 2) 음죽현, 본고구려노음죽현, 경덕왕개명, 금인지.

eumjukeon, bongoguryeonoeumjukeon, gyeongdeokwanggaemyeong, geuminji.

In example (61) we see the correspondence 城 $=$ 忽, so we can assume the relationship 陰=仍, and the relationship 陰=奴音 in example (62). 仍 is *njoy and 奴 is *na in ancient Chinese, therefore, 奴音 becomes *nam because the final consonant of 音 is ' $m$ '. This suggests that the nasal sounds ' $y$ ' and ' $m$ ' are neutralized, except for the onset position.

\section{Development in the usages of Chinese characters}

4.1 The limit of the sound-borrowing characters in the Korean Peninsula

(63) 南川県、一云南買。(Vol. 37, g. j. 4 高句麗・黄武県)

남천현, 일운남매. (고구려·황무현)

namcheonhyeon, ilunnammae. (goguryeo $\cdot$ hwangmuhyeon)

(64) 内乙買、一云内爾米。（Vol. 37, g. j. 4 高句麗・沙川県）

내을매, 일운내이미. (고구려·사천현)

naeeulmae, ilunnaeimi. (goguryeo $\cdot$ sacheonhyeon)

(65) 買召忽県、一云弥鄒忽。（Vol. 37, g. j. 4 高句麗・邵城県）

매소홀현, 일운미추홀. (고구려 - 소성현)

maesoholhyeon, ilunmichuhol. (goguryeo $\bullet$ soseonghyeon)

(66) 休壌郡、一云金悩。(Vol. 37, g. j. 4)

휴양군, 일운금뇌.

hyuyanggun, ilungeumnoe. 
(67) 黒壌郡(一云黄袞郡)、本高句麗今勿奴郡、景徳王改名、今鎮州。(Vol. 35, g. j. 2)

\section{흑양군(일운황양군), 본고구려금물노군, 경덕왕개명, 금진주.}

heukyanggun (ilunhwangyanggun), bongoguryeogeummullogun, gyeongdeokwanggaemyeong, geumjinju.

$$
\begin{aligned}
& \text { (68) 今勿奴郡、一云万妲。(Vol. 37, g. j. 4) } \\
& \text { 금물노군, 일운만노. } \\
& \text { geummullogun, ilunmanno. }
\end{aligned}
$$

(69) 槐壌郡、本高句麗仍斤内郡、景徳王改名、今槐州。(Vol. 35, g. j. 2) 괴양군, 본고구려잉근내군, 경덕왕개명,금괴주.

goeyanggun, bongoguryeoinggeunnaegun, gyeongdeokwanggaemyeong, geumgoeju.

The borrowed sounds of 川 is 買, 米 or 弥, and in the case of 壤〈area〉, there are options of 悩, 奴 or 驽 and 内. We can assume that the varieties in syllable notations are due to the different dialects and different periods. Differences in deciding what form these syllables should be written and how to write them seemed to occur synchronically. It was not the matter of how to borrow characters, but more about how to write down the sounds which were different from the sounds in the Chinese language. It was very confusing to make decisions for the sounds in the Goguryeo language which was quite different from Chinese. Since the sounds in Goguryeo and Silla languages could not be transcribed with Chinese sound-borrowing characters, either in the logic of zen'on-gana or rengô-gana, and also since the Tungus languages in Goguryeo and the Korean of Silla had different native words, it must have been difficult to make choices when Silla was forced to accept the writing system of Goguryeo. Though there were various ways to devise the notation, it was still a complex matter particularly for readers.

In Silla in mid- $8^{\text {th }}$ century, as symbolized by the renaming by the King Gyeongdeok (景徳王改名) in the geographical journal of Samguk Sagi, the Sinicization or Chinalization gradually advanced. The Chinalization in case of the language was the language changes into more Chinese language practice, among them on-doku (音読, Chinese pronunciation of Chinese characters). As a result, after Silla (A.D. 676 ) became united, the use of Chinese characters itself became primary, and the writing system in which a line of specific words and characteristics native to the three countries to be recorded with additional notations remained only in limited use. Thus, idok 吏読, gugyeol 口訣, and hyangga had less and less range of use, and kun-yomi (native or semantic reading) also declined. The sound-borrowing characters 音借字 remained only for auxiliary usages. 
On the other hand, Japanese syllables, thanks to their simple structure, were subsumed into the syllable structures of Chinese characters. Therefore, in Japan, the man'yôgana-bun ${ }^{23}$ appeared as symbols for phonetic notations. Man'yôgana-bun that appeared in the $7^{\text {th }}$ century was not only for poetry, but also for prose in the $8^{\text {th }}$ century. (It is worth noting, that in the 8th century, while Chinese culture had more and more influence on Silla, in Japan appeared the system of text composition only with the syllabic letters. This period may be the diverging point of Chinese-character culture in two nations.)

(70) 和可夜之奈比乃可波利尔波於保末之末須美奈美乃末知奈流奴乎宇気与止於 保止己口都可佐乃比止伊布...... (Shôsôin kana documents, around yr.762)

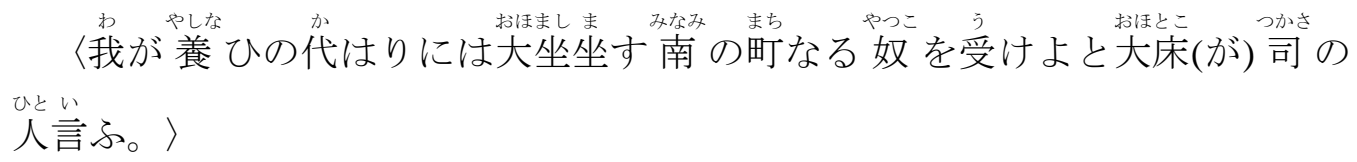

waga yasinafi no kafari niha oomasi masu minami no mati naru yatsuko wo ukeyo to ohotoko ga tukasa no hito ifu.

In the text body with syllabic characters, it is common that words such as 奴 above which has to be read as 'yatsuko' in kun-reading were mixed with sound-borrowing characters. Later, it was also common to write ondoku-go (音読語, on-reading words) as kango (漢語, originally Chinese words) by Chinese characters. Even after the transfer into hiragana-bun ${ }^{24}$, there was no change with the form of kanji-majirihiragana-bun 漢字交じり平仮名文 ${ }^{25}$. The use of hiragana-bun text in the Heian period spreads among the women of aristocracy, and in mid-12 $2^{\text {th }}$ century, texts such as Kanagaki Ojoyôshû 『仮名書往生要集』were already written in hiragana for the kanbun-kundoku (Chinese classics in semantic reading). Afterwards, katakana separated from the limited use in the kun-reading of Chinese classics (kun-doku 訓読), and its usage expanded in the $13^{\text {th }}$ century in the upper class society of farmers in Japan. Thus, by the independence of kana which was now used without any constraint, the unique writing system was consolidated together with Chinese characters for both substantial words written in kun-reading and originally Chinese words in on-reading.

23 万葉仮名文 Texts or sentences which were written using manyôgana. Cf. see section 3.1 in this article, manyôgana $=$ (Japanese sound-borrowing letters $)$.

${ }^{24}$ Hiragana-bun 平仮名文 Texts or sentences written by using hiragana, one of the Japanese syllabaries.

${ }^{25}$ Kanji-majiri-hiragana-bun 漢字交じりひらがな文 Texts or sentences written by using hiragana and kanji (Chinese characters). 


\subsection{Chinese characters as ideograms and inevitable consequences}

Chinese characters are called ideograms (hyôi moji). For example, the Chinese character 三 means 〈(number of) 3$\rangle$, and expresses the sound san. It stands not only for the meaning, but also for a language unit or a word, therefore it is appropriate to call it a logogram (hyogo moji). If another language, particularly of a different type of a language system, borrows the system of logograms, then the original sounds of the logogram system will be inherited. On the other hand, understanding specific meanings of words by reading them semantically has been often practiced in history. For example, the Akkadian language of Semitic languages borrowed cuneiform scripts (Sumer letters), thus the writing system is phonetically based on Sumerian, but semantic uses are also observed with the ' $k u n$ ' (or 'semantic') readings in Akkadian. Logographic letters, when they are more and more digested and absorbed in the new local language, it is easier to understand individual letters or characters in the native language. It is also more rational and natural to do so. In other words, kun is a common phenomenon that occurs when a system of logograms is borrowed by another language which differs greatly from the former. (The final consonant notation and okuri-gana 送り仮名 are also established as byproducts of the phenomenon of borrowing logograms.)

When this native semantic reading kun declines, the characteristic of letters being logograms becomes a surplus. The decline of kun-reading in Korean made it difficult to recognize the original Chinese characters with their visual meanings, and the semantic differentiation of characters became ineffective. As a result, it was a natural course of development that the language diverged from the logogram system of writing.

In Japan during the Edo period, the literacy spread to the upper layer of the common people, the amount of publication increased, and the addition of the reading aid by attaching hiragana to Chinese characters, i.e. furigana 振り仮名 in wood-print publications became quite common. Furigana was used for on 音 and kun 訓, and the sô-ruby (総ルビ, the furigana next to every Chinese character), and the custom continued until 1945. This notation system in reality is written in kana, and through the furigana's kun, each character represented a meaning. In 1946, the number of Toyo Kanji 当用漢字 was decided to be 1850, and furigana was abandoned. Meanwhile, the fixed on-kun 音訓 was allocated to each logogram to understand Chinese characters. (In 2010, Jôyô Kanji 常用漢字 was decided, total number of 2136 and the number of kun readings 2036.) Chinese characters are useable by their kun-reading with each specific semantics, and this coincides with the essential nature of logograms or the Chinese characters. Hence the Chinese characters fit well into the Japanese language and are ever more convenient to use. 


\section{Appendix: Transcription rules}

Vowel letters

\begin{tabular}{|c|c|c|c|c|c|c|c|c|c|}
\hline$f[a]$ & $-1[0]$ & $\perp[\mathrm{o}]$ & $\mathrm{T}[\mathrm{u}]$ & $-[\mathrm{w}]$ & | [i] & $H[\varepsilon]$ & $\|$ [e] & $\begin{array}{l}\mid \\
\text { [we] }\end{array}$ & $\begin{array}{l}\text { Tl } \\
\text { [wi] }\end{array}$ \\
\hline $\mathrm{a}$ & eo & o & $\mathrm{u}$ & $\mathrm{eu}$ & $\mathrm{i}$ & ae & $\mathrm{e}$ & oe & wi \\
\hline
\end{tabular}

\begin{tabular}{|c|c|c|c|c|c|c|c|c|c|c|}
\hline al & $\begin{array}{l}7 \\
\text { [yə] }\end{array}$ & \begin{tabular}{|l}
$\Perp$ \\
[yo]
\end{tabular} & $\begin{array}{l}\pi \\
{[\mathrm{yu}]}\end{array}$ & $\begin{array}{l}\text { H } \\
\text { [y }]\end{array}$ & 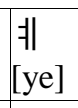 & $\begin{array}{l}\text { 나 } \\
\text { [wa] }\end{array}$ & \begin{tabular}{|l} 
내 \\
[we]
\end{tabular} & \begin{tabular}{|l} 
TA \\
[wa]
\end{tabular} & $\begin{array}{l}\text { Tin } \\
\text { [we] }\end{array}$ & -1 \\
\hline & yeo & yo & yu & yac & ye & w: & wa & wo & we & ui \\
\hline
\end{tabular}

Consonant letters

\begin{tabular}{|c|c|c|c|c|c|c|c|c|c|c|}
\hline Hangul & & $\neg[\mathrm{g}, \mathrm{k}]$ & $77\left[\mathrm{k}^{\prime}\right]$ & $\llcorner[\mathrm{n}]$ & $\mid \begin{array}{l}\mathrm{C}[\mathrm{d}, \\
\mathrm{t}]\end{array}$ & {$\left[\mathrm{LC}\left[\mathrm{t}^{\prime}\right]\right.$} & ᄅ [1] & $\square[\mathrm{m}]$ & $\forall[\mathrm{b}, \mathrm{p}]$ & $\forall\left[p^{\prime}\right]$ \\
\hline \multirow{2}{*}{ Romanization } & Initial & $\mathrm{g} \mathrm{p}$ & $\mathrm{kk}$ & $\mathrm{n}$ & $\mathrm{d}$ & tt & $\mathrm{r}$ & $\mathrm{m}$ & $\mathrm{b}$ & $\mathrm{pp}$ \\
\hline & Final & $\mathrm{k}$ & $\mathrm{k}$ & $\mathrm{n}$ & $\mathrm{t}$ & - & 1 & $\mathrm{~m}$ & $\mathrm{p}$ & F \\
\hline
\end{tabular}

\begin{tabular}{|c|c|c|c|c|c|c|c|c|c|}
\hline ᄉ $[\mathrm{s}]$ & $\mu\left[\mathrm{s}^{\prime}\right]$ & $O[\mathrm{n}]$ & $\mid \begin{array}{l}\pi[\mathrm{d} \\
\mathrm{ts}]\end{array}$ & तx [ts'] & 大 $\left[\mathrm{ts}^{\mathrm{h}}\right]$ & $\Rightarrow\left[\mathrm{k}^{\mathrm{h}}\right]$ & ]$\in\left[\mathrm{t}^{\mathrm{h}}\right.$ & ] 표 $\left[\mathrm{p}^{\mathrm{h}}\right]$ & $\mathrm{h}]$ ᄒ [h] \\
\hline$S$ & ss & - & j & $\mathrm{jj}$ & $\mathrm{ch}$ & $\mathrm{k}$ & $t$ & $\mathrm{p}$ & $\mathrm{h}$ \\
\hline t & $\mathrm{t}$ & ng & $t$ & - & $\mathrm{t}$ & $\mathrm{k}$ & $t$ & $\mathrm{p}$ & $\mathrm{t}$ \\
\hline
\end{tabular}

\section{References}

Ikegami, Jirô 池上二良（1989）「ツングース諸語」(Tungusic Languages) 『言語学大辞 典』(Lexicon of Linguistics, Vol. 2, pp. 1058-1083) 三省堂 Sanseido, Tokyo.

Inoue, Hideo (ed.) 井上秀雄訳注 (1986)『三国史記』3（東洋文庫 454 平凡社）Samguk Sagi, Heibonsha, Tokyo.

Lee, Gi-Mun 李基文（1975）『韓国語の歴史』(History of the Korean Language) 大修館 書店 Taishûkan, Tokyo（『国語史概説』1961 Seoul）

Mabuchi, Kazuo; I, In'yon \& Ôhashi, Yasuo 馬淵和夫 ・李寅泳・大橋康子( 1979)「『三国 史記』記載の「高句麗」地名より見た古代高句麗語の考察」文芸言語研究・言語 篇 4 (A study on the ancient Goguryeo language based on the Goguryeo geographical names in Samguk Sagi, Bungei Gengo Kenkyû: Languages 4, pp. 1-47) 